\title{
Pengelolaan Destinasi Wisata Danau Toba Melalui Persepsi Masyarakat Setempat
}

\author{
Afrilia Elizabet Sagala ${ }^{1}$ \\ ${ }^{1}$ Sekolah Tinggi Pariwisata Sahid Surakarta \\ ${ }^{1}$ Email; afriliaelizabetsagala@stpss.ac.id
}

\begin{abstract}
In tourism development, community participation is very important. Community participation does not just appear but must start from the right perception of tourism. Local people, with all their perceptions about tourism management, have been involved in tourism management. The purpose of this study was to determine the local community's perception of the manager of the main tourism destinations and to determine the sustainable tourism development model in Simanindo District, Samosir Regency. This type of research is a social survey and descriptive-quantitative. The technique used in sampling is the Franc Lynch method, with a sample of 95 people as respondents, aged 15-64 years old. The type of data used is primary by using a questionnaire with a Likert scale in each question. The data analysis technique used is value perception and multiple regression analysis. The results of this study show: 1) The percentage of the average value of the independent variable is $85 \%$, this means that the perception of the local community about the management principles of Lake Toba tourist destinations is in a positive or good area 2) Sustainable tourism development has a positive relationship and influenced simultaneously by service, attractiveness, human resources, environment, and participation. Therefore, the sustainable tourism development model must emphasize the attractiveness and human resources in Simanindo District.
\end{abstract}

Keywords: Community tourism development, sustainable community, sustainable tourism Article Information: Submission: 09 Agustus 2021, Accepted: 10 Agustus 2021, Published: 10 Agustus 2021 DOI:

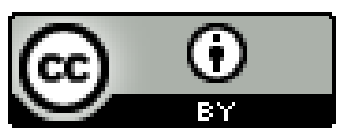

Copyright ( 2021 by the author(s). This article is published by Sekolah Tinggi Pariwisata Sahid Surakarta, Indonesia under the Creative Commons Attribution (CC BY 4.0) license. Anyone may reproduce, distribute, translate, and create derivative works of this article (for both commercial and noncommercial purposes), subject to full attribution to the original publication and author(s). The full terms of this license may be seen at https://creativecommons.org/licenses/by/4.0/

\section{PENDAHULUAN}

Danau Toba adalah sebuah danau kawah seluas $1.145 \mathrm{~km} 2$ di tengahnya hidup sebuah pulau dengan luas yang hampir sebanding dengan wilayah Singapura. Danau Toba adalah danau terbesar di Asia Tenggara dan terbesar kedua di dunia setelah Danau Victoria di Afrika. Danau Toba juga termasuk danau terdalam di dunia, yaitu 
sekitar 450 meter. Danau Toba diperkirakan terbentuk setelah letusan supervolcanic sekitar 73.000-75.000 tahun lalu. Pada waktu itu, 2.800 km kubik material vulkanik yang dimuntahkan keluar oleh Gunung Toba yang meletus hingga vulkanik debu di angin menyebar ke setengah dari bumi wilayah. Letusannya terjadi selama satu minggu, dan ketapel mencapai $10 \mathrm{~km}$ di atas permukaan laut. Bahwa itulah kenapa Danau Toba bisa dikatakan alami keajaiban di Pulau Sumatera Utara. Keindahan Danau Toba dan Pariwisatanya Potensi yang ada di sekitar Kecamatan Simanindo adalah aset berharga bagi daerah dan pusat pemerintah karena merupakan salah satu negara pendapatan devisa. Industri pariwisata yang dibangun tentu akan berdampak besar, seperti peningkatan pendapatan, penciptaan lapangan kerja baru, dan pertumbuhan ekonomi yang positif melalui kunjungan wisatawan. Realitas yang ditemukan berbeda menurut Badan Pusat Statistik (BPS). Jumlah wisatawan asing yang masuk ke Sumatera Utara melalui Bandara Kualanamu pada Januari 2016 mengalami penurunan sebesar 47,41\% dibandingkan Desember 2015, sedangkan dibandingkan Januari 2015 terjadi penurunan sebesar 41,69\%. Semua pariwisata di Sumatera Utara memiliki menurun, termasuk Danau Toba. Jumlah kunjungan wisatawan Nusantara saat musim liburan 2015 ke Danau Toba Destinasi juga menurun dibandingkan dengan musim liburan yang sama pada tahun 2014.

Kepala Organisasi Manajemen Destinasi (DMO) menjelaskan jumlah kunjungan Wisatawan Nusantara menuju Destinasi Danau Toba melalui pintu masuk Kabupaten Parapat Simalungun mencapai rata-rata 22.000 jiwa setiap hari, dimana wisatawan didominasi dari Riau dan Sumatera Barat. Itu berangkat dari peraturan pemerintah Nomor 50 Tahun 2011 tentang Negara Rencana Induk Pengembangan Pariwisata 20102025. Pemerintah pusat akhirnya membuat Danau Toba salah satu dari sepuluh tujuan wisata prioritas pemerintah akan berkembang. Visi ini peraturan pemerintah adalah menjadikan Danau Toba sebagai Pemandangan Lanskap dan Geopark. Tujuan dari peraturan ini sendiri adalah untuk meningkatkan wisatawan asing kedatangan menjadi 1 juta orang pada tahun 2019. Target pasar wisman dibidik di ASEAN (Malaysia dan Singapura), EROPA (The Belanda dan Prancis), Australia, Amerika), sedangkan pasar wisata domestik, seperti besar kota di Jawa dan
Sumatera. Pengembangan kawasan wisata Danau Toba strategi menekankan Atraksi, Fasilitas, dan Aksesibilitas yang sebagian besar bersifat fisik pengembangan. Bahkan, citra turis destinasi yang juga berkontribusi terhadap Kehadiran wisatawan tidak hanya terbentuk melalui infrastruktur wisata, atraksi, dan alam Kecantikan. Sebaliknya, itu juga dibentuk oleh sikap masyarakat sekitar wisatawan tujuan. Jadi, pengembangan Danau Kawasan pariwisata Toba juga harus mendapat dukungan dari masyarakat sekitar. Dalam pengembangan pariwisata, khususnya Danau Toba, partisipasi masyarakat itu penting bagian.

Partisipasi masyarakat merupakan salah satu faktor penentu sekaligus sebagai indikator keberhasilan dan keberlanjutan pembangunan. Itu nilai modal sosial yang terkandung dalam komunitas partisipasi adalah salah satu yang membentuk pariwisata pengembangan. Beberapa daerah, seperti Bali dan Yogyakarta, berhasil menjadi turis destinasi dengan memberdayakan masyarakat lokal untuk berkontribusi untuk meningkatkan pembangunan dan menjaga pariwisata.

Oleh karena itu, pengembangan pariwisata harus melibatkan masyarakat lokal secara langsung masyarakat dan sekitarnya. Pembangunan harus menerapkan prinsip desentralisasi, bergerak dari bawah (bottom-up), libatkan masyarakat secara aktif (partisipatif), dilakukan dari dan dengan with orang (dari dan dengan orang). Demikian pula pariwisata manajemen membutuhkan keterlibatan semua pemangku kepentingan di sektor pariwisata untuk mengintegrasikan kerangka manajemen pariwisata. Ini pemangku kepentingan harus mampu mengintegrasikan dan terwakili dalam perencanaan, pengembangan, dan pengoperasian suatu destinasi wisata.

Pengelolaan pariwisata harus bersinergi dalam memenuhi prinsip - prinsip manajemen. Diperlukan metode manajemen yang memastikan pelibatan seluruh pemangku kepentingan pariwisata, melibatkan partisipasi masyarakat setempat. Tentu saja, partisipasi masyarakat tidak muncul begitu saja tapi harus dimulai dari persepsi masyarakat yang benar pariwisata. Setelah persepsi yang benar adalah terbentuk, maka masyarakat dapat aktif terlibat dalam perencanaan, pelaksanaan, pemantauan, menerima, dan memanfaatkan hasil pariwisata pengembangan. Wienburg dan Wilmot 
menyatakan bahwa persepsi adalah cara memberi makna, sedangkan Persepsi Verderbe menafsirkan sensorik informasi. Persepsi memungkinkan manusia untuk mendapatkan pengetahuan baru. Persepsi mengubah sensasi ke dalam informasi.

Jika sensasi adalah sensorik proses kerja, maka persepsi adalah jalannya individu memproses data sensorik menjadi informasi sehingga dapat diinterpretasikan. Penjelasan di atas menunjukkan bahwa manusia persepsi itu unik. Keunikannya terletak pada persepsi yang berbeda di antara manusia yang sama rangsangan. Manusia dapat secara biologis dan secara psikologis memiliki banyak kesamaan, tetapi mereka persepsi objek tidak akan pernah sama. Semakin besar perbedaan biologis dan pengalaman antar individu, semakin besar kesenjangan yang dirasakan di antara mereka. Sebaliknya, semakin kecil perbedaan biologis dan pengalaman antar individu, semakin kecil disparitas persepsi manusia dengan dunia luar. Persepsi kelompok terjadi ketika beberapa individu memiliki persepsi yang sama tentang dunia luar.

Komunikasi yang terjadi di kelompok tertentu lebih mudah dilakukan tetapi akan will lebih kompleks jika melibatkan latar belakang yang berbeda antar pelaku komunikasi. Hal ini terkait dengan pernyataan Samovar, persepsi adalah bagaimana budaya mengajarkan anggotanya untuk melihat dunia berbeda. Artinya, budaya mempengaruhi bagaimana masing-masing anggota merasakan, melihat, atau memahami sesuatu. Persepsi, jika dikaitkan dengan antarbudaya konteks, muncul karena penilaian setiap orang dan pemilihan orang lain diukur berdasarkan masuknya budayanya sendiri. Selanjutnya, persepsi akan memilih apa yang diterima atau ditolak oleh peserta komunikasi. Sama persepsi akan memfasilitasi komunikasi peserta untuk mencapai kualitas yang diharapkan hasil komunikasi. Masyarakat di Kecamatan Simanindo memiliki latar belakang budaya yang berbeda dari wisatawan karena mereka lahir dan besar di daerah masyarakat asli Batak Toba.

Pengetahuan atau pengalaman budaya sangat berbeda dari turis. Semua referensi menerima sesuai dengan mereka identitas budaya akan menentukan kerangka atau bagaimana memahami sesuatu. Orang Batak lebih suka dipanggil namaradat, memiliki adat (adat, tradisi) daripada agama karena jika mereka tidak beragama, mereka tidak cocok untuk menjadi anggota masyarakat. Orang Batak akan terus mengamalkan ajaran Batak adat meskipun telah dianut Kekristenan. Dalam hal ini, budaya sebagai Batak komunitas akan lebih kuat dari kekristenan. Masyarakat Batak tidak dianggap sesuatu yang sangat ketat, tetapi jika seseorang dipanggil naso maradat, maka orang itu tidak lagi berhak menjadi anggota masyarakat. Itu Budaya Batak menjunjung tinggi kehormatannya sebagai Anak Ni Raja dan Boru Ni Raja, yang dilaksanakan di Dalihan Natolu (Kekerabatan Batak Toba). Itu Arti Anak Ni Raja dan Boru Ni Raja bagi masyarakat lokal adalah bentuk untuk bertindak hormat.

Mereka harus sopan kepada orang Batak, seperti kesopanan terhadap putra dan putri raja. Pengertian pariwisata dalam undang-undang nomor 10 tahun 2009 menekankan layanan yang diberikan oleh masyarakat dan prinsip-prinsip berkelanjutan manajemen Pariwisata. Menurut Dowling dan Fannel, pelayanan kepada wisatawan harus diberikan. Tentu saja, itu kontras dengan persepsi yang timbul dari budaya orang Batak di Kabupaten Simanindo, yang bertingkah seperti orang lain harus dengan hormat sopan kepada mereka sebagai putra dan putri raja. Belum lagi harga produk pariwisata yang relatif tinggi, membuat wisatawan jera dan enggan untuk kembali. Kabupaten Simanindo, dengan berbagai wisatanya potensi yang disertai dengan pengembangan strategi kawasan wisata Danau Toba, berbalik keluar bertentangan dengan kedatangan asing wisatawan melalui pintu bandara Kualanamu, yang cenderung menurun. Sangat menarik untuk dipelajari, Apalagi jika dikaitkan dengan budaya lokal masyarakat. Persepsi masyarakat setempat yang bekerja di bidang usaha pariwisata perlu diteliti karena merupakan salah satu faktor kunci keberhasilan pariwisata berkelanjutan pengembangan.

\section{METODE PENELITIAN}

Penelitian ini dilakukan di Simanindo Kecamatan, Kabupaten Samosir, Sumatera Utara Provinsi, dan dilaksanakan pada bulan Maret Oktober 2018. Lokasi penelitian dipilih karena Simanindo terletak persis di tepi pantai Danau Toba yang terhubung dengan dermaga Parapat. Selain itu, Kabupaten Simanindo memiliki kekayaan wisata alam, sejarah, budaya, dan 
kearifan lokal yang bisa menjadi daya tarik untuk wisatawan. Populasi adalah area generalisasi terdiri dari objek-objek atau subjek-subjek dengan kualitas dan karakteristik yang ditentukan oleh peneliti untuk dipelajari dan disimpulkan. Populasi penelitian ini adalah Simanindo masyarakat berusia 15-64 tahun. Berdasarkan data diperoleh dari Badan Pusat Statistik (BPS) Kabupaten Samosir pada tahun 2016 diketahui bahwa penduduk Kecamatan Simanindo usia 1564 tahun berjumlah 11.929 orang. Itu sampel populasi dihitung dengan menggunakan rumus Frank Lynchch.Sugiyono menjelaskan bahwa purposive sampling adalah teknik pengambilan sampel dengan pertimbangan tertentu.

Dalam hal ini, penulis mengambil sampel berdasarkan pengamatan di Masyarakat Kecamatan Simanindo yang menjadi tenaga kerja di bidang usaha pariwisata. Selain menjadi komunitas lokal yang produktif, mereka juga berperan langsung dalam mengelola pariwisata sesuai dengan bisnis yang mereka geluti. Metode pengumpulan data dalam penelitian ini adalah wawancara dan dokumentasi. Wawancara dan daftar pertanyaan (kuesioner) diberikan kepada responden penelitian. Dokumentasi studi adalah dilakukan dengan mempelajari data dari Simanindo Kantor Kabupaten dan Badan Pusat Statistik situs web. Jenis dan sumber data dalam penelitian ini adalah data primer dan sekunder. Data primer adalah diperoleh langsung dari sumbernya (lapangan), melalui kuesioner dan wawancara. Data sekunder diperoleh dari studi literatur berupa dokumen resmi yang diterbitkan oleh Central Badan Pusat Statistik dan buku-buku lain, misalnya, data penduduk.

\section{DISKUSI DAN DAN HASIL}

Persepsi masyarakat setempat tentang prinsip pengelolaan destinasi wisata di tourist Kecamatan Simanindo berada di wilayah positif sebesar $85 \%$. Saya t sangat besar untuk pariwisata berkelanjutan pembangunan di Simanindo. Ketika lokal persepsi masyarakat tentang pengelolaan prinsip pariwisata adalah positif, pada saat yang sama, peran masyarakat dapat dioptimalkan untuk mewujudkan pariwisata berkelanjutan. Karena pariwisata pembangunan, bukan hanya tugas pemerintah dan sektor swasta, tetapi yang paling yang penting adalah peran masyarakat setempat. Partisipasi masyarakat merupakan salah satu prasyarat untuk penerapan konsep dari pemerintahan yang baik. Pemerintahan yang bagus, menurut Pembangunan PBB Program (UNDP), adalah kesepakatan tentang peraturan negara yang dibuat bersama oleh pemerintah, masyarakat sipil, dan sektor swasta [19]. Begitu juga dengan pengembangan pariwisata, tidak bisa terlepas dari perannya masyarakat lokal. Itu masyarakat lokal memiliki beragam dan keunikan sumber daya yang tidak dimiliki oleh pemerintah dan swasta. Sumber daya ini dan keunikan menjadi elemen pendorong utama pengembangan pariwisata berkelanjutan. Berdasarkan hasil regresi estimasi dan uji simultan, diketahui bahwa pembangunan pariwisata berkelanjutan memiliki hubungan positif dan dipengaruhi oleh variabel simultan pada variabel layanan atraksi, sumber daya manusia, lingkungan, dan partisipasi. Oleh karena itu, pariwisata berkelanjutan pembangunan berbasis masyarakat lokal, dapat diarahkan pada poin-poin berikut:

1. Meningkatkan kemampuan masyarakat lokal pelayanan kepada wisatawan yang mengunjungi wisatawan destinasi dengan mengutamakan keramahan dan kesediaan untuk membantu.

2. Pelestarian dan penciptaan alam dan daya tarik wisata budaya sebagai sumber keunikan dan daya tarik wisata.

3. Meningkatkan kapasitas dan kualitas masyarakat di bidang pariwisata.

4. Meningkatkan posisi dan partisipasi masyarakat dalam merencanakan, melaksanakan, pemantauan, dan evaluasi pariwisata pengembangan

5. Pelestarian Lingkungan Pengembangan pariwisata berkelanjutan yang berbasis komunitas lokal dapat diarahkan oleh meningkatkan kapasitas, peran, kualitas, kedudukan, dan peran masyarakat. Namun, berdasarkan hasil pengujian secara parsial, dua variabel secara signifikan mempengaruhi pariwisata berkelanjutan pembangunan, yaitu atraksi dan manusia sumber daya.

Tempat wisata adalah salah satu yang krusial komponen pariwisata. Ada dua fungsi daya tarik, pertama sebagai perangsang atau umpan wisata, dan kedua sebagai salah satu bahan pokok produk pariwisata dan tujuan utama faktor pengunjung. Pariwisata harus dikelola dengan baik oleh masyarakat setempat, apapun bentuknya, baik alam, budaya, atau kepentingan khusus. Eksploitasi besar-besaran, keengganan untuk 
melestarikan, dan minus penciptaan dan inovasi dapat menghilangkan daya tarik dan bahkan masuk akal untuk kehilangan label sebagai sebuah tujuan wisata. Pengelolaan tempat wisata yang dimiliki Simanindo tidak terlepas dari dukungan masyarakat setempat. Lokal dukungan masyarakat dimulai dengan melestarikan alam syarat dengan menyediakan tempat sampah, sampah perlakuan, penetapan aturan dengan pemangku kepentingan, dan mensosialisasikannya. Jadi, objek wisata alam objek wisata tetap terjaga keindahan panoramanya. Pelestarian alam dan budaya harus berkelanjutan.

Itu berarti mereka dapat diwarisi dari generasi ke generasi, misalnya dengan mengadakan budaya Batak Toba secara teratur pertunjukan. Selain itu, yang penting adalah menjaga stabilitas air, udara, flora, dan fauna di Simanindo. Perkembangan wisatawan tujuan tidak selalu berarti menebang pepohonan, perusakan habitat fauna, dan pencemaran udara. Eksploitasi alam yang berlebihan dan pengabaian keseimbangan dan kondisinya pasti bisa merusak lingkungan. Bahkan bisa mengubah budaya dan perilaku masyarakat setempat. Oleh karena itu, lokal rakyat dan pemerintah harus mengontrol perizinan pengembangan kawasan wisata yang cenderung that alih fungsi lahan. Selanjutnya, melestarikan dan meningkatkan tempat wisata juga bisa dilakukan dengan inovasi dan kegiatan pariwisata budaya dan Ketertarikan spesial. Inovasi dan kreativitas wajib untuk merangsang sesuatu untuk dilakukan, sesuatu untuk dilihat, dan sesuatu untuk dibeli turis. Kreativitas dan inovasi dapat dilakukan, misalnya dengan mengatur transportasi lokal local fasilitas untuk memudahkan wisatawan mengunjungi berbagai situs turis.

Harga yang terjangkau juga berkontribusi pada wisatawan memilih untuk menikmati keindahan turis objek wisata di Kecamatan Simanindo. Mahal tiket masuk untuk menikmati keindahan dan keunikan tempat wisata di Kecamatan Simanindo bisa mengakibatkan penurunan minat wisatawan dan terlihat sebagai penghambat arus wisatawan ke Kecamatan Simanindo. Tentu saja, analisis harga adalah salah satu masalah tersulit yang harus dihadapi dalam ekonomi pariwisata. Berdasarkan penelitian ini, atraksi dan sumber daya manusia memiliki pengaruh positif yang signifikan pengaruhnya terhadap pembangunan pariwisata berkelanjutan di Kecamatan Simanindo. Artinya kualitas quality sumber daya manusia harus ditingkatkan untuk mendukung pengembangan pariwisata. Sumber daya manusia, dalam hal ini kasus, masyarakat lokal, diharuskan untuk memahami pariwisata, berperan aktif dalam asosiasi pariwisata, dan penguasaan asing bahasa.

Pariwisata dapat dieksplorasi lebih jauh jika penduduk setempat masyarakat bergabung dengan asosiasi pariwisata. Itu pergaulan memberikan manfaat dan besar peluang bagi masyarakat lokal untuk berkembang pariwisata. Bergabung dengan asosiasi menyediakan setidaknya lima manfaat, termasuk pembelajaran yang lebih besar kesempatan, peningkatan pengalaman dan wawasan, kolaborasi dalam lingkungan sosial, memperluas jaringan, dan sumber inspirasi dan informasi. Salah satu prasyarat untuk pariwisata pembangunan dapat dicapai dengan adanya asosiasi masyarakat lokal yang peduli dengan pariwisata. Dengan demikian, masyarakat setempat memiliki kemauan untuk berpartisipasi, memiliki tujuan bersama, dan bekerja sama dalam mengembangkan pariwisata dengan berbagai keahlian dan jaringan yang mereka miliki dalam asosiasi.

Sebagai ditunjukkan di Glen and Mears, pariwisata asosiasi adalah pemangku kepentingan penting dalam rantai pasokan pariwisata, karena mereka bertindak sebagai saluran antara pemerintah dan swasta. Hal yang tak kalah penting dan wajib bagi masyarakat lokal adalah berbicara bahasa asing. Kemampuan berbicara bahasa asing adalah penting karena wisatawan yang berkunjung juga datang dari negara lain. Ketidakmampuan orang asing bahasa dapat menjadi kendala dalam berkomunikasi. Bahkan, keterampilan komunikasi dalam budaya antar konteks adalah persyaratan penting bagi orang dalam industri pariwisata. Selain itu juga menunjukkan bahwa tujuan wisata endemik tingkat dunia.

\section{Referensi}

Vazquez, J.A., dan M.Reir. 2004. Menyelidiki sejarah akumulasi volumetrik Magma Toba. Ilmu Bumi dan Antariksa. Universitas California. Los Angeles.

Pusat Statistik. 2016. Statistik Regional Kabupaten Simanindo 2015. Pusat Statistik Katalog. Kabupaten Samosir. 
Kas Negara. 2011. Pemerintah Perda No. 50 Tahun 2011 Kepariwisataan Nasional Rencana Induk Pembangunan 2010-2025. Republik Indonesia. Jakarta.

Wenburg, J. R., dan W. W. Wilmot. 2007. Proses komunikasi pribadi. Jhon Wiley dan Putra. New York.

Verderber, R. F., dan K. S. Verderber. 2005. Menyampaikan. Wadsworth. AMERIKA SERIKAT.

Samovar, L.P. 2010. Komunikasi lintas budaya. Salemba Humanika. Jakarta.

Dowling, R., dan D. Adas. 2003. Konteks kebijakan dan perencanaan ekowisata. Gramedia Pustaka Utama. Jakarta.

Hariyana, K. 2015. Persepsi masyarakat terhadap pengembangan kawasan Goa Peteng sebagai daya tarik wisata di Desa Jimbaran Kuta Selatan Kabupaten Badung. Jurnal Destinasi Wisata 3(1), 24-34. 